\title{
QUEEN'S
UNIVERSITY
BELFAST
}

\section{Identification of lactic acid bacteria strains modulating incretin hormone secretion and gene expression in enteroendocrine cells}

Panwar, H., Calderwood, D., Gillespie, A. L., Wylie, A. R., Graham, S. F., Grant, I. R., Grover, S., \& Green, B. D. (2016). Identification of lactic acid bacteria strains modulating incretin hormone secretion and gene expression in enteroendocrine cells. Journal of Functional Foods, 23, 348-358. https://doi.org/10.1016/j.jff.2016.02.040

Published in:

Journal of Functional Foods

Document Version:

Peer reviewed version

Queen's University Belfast - Research Portal:

Link to publication record in Queen's University Belfast Research Portal

Publisher rights

(C) 2016 Elsevier Ltd. This manuscript version is made available under the CC-BY-NC-ND 4.0 licensehttp://creativecommons.org/licenses/by$\mathrm{nc}-\mathrm{nd} / 4.0 /$, which permits distribution and reproduction for non-commercial purposes, provided the author and source are cited

\section{General rights}

Copyright for the publications made accessible via the Queen's University Belfast Research Portal is retained by the author(s) and / or other copyright owners and it is a condition of accessing these publications that users recognise and abide by the legal requirements associated with these rights.

Take down policy

The Research Portal is Queen's institutional repository that provides access to Queen's research output. Every effort has been made to ensure that content in the Research Portal does not infringe any person's rights, or applicable UK laws. If you discover content in the Research Portal that you believe breaches copyright or violates any law, please contact openaccess@qub.ac.uk. 
1 Identification of lactic acid bacteria strains modulating incretin hormone secretion and

2 gene expression in enteroendocrine cells

3 Harsh Panwar ${ }^{1,2 \#}$, Danielle Calderwood ${ }^{1}$, Anna L Gillespie ${ }^{1}$, Alastair R Wylie ${ }^{4}$, Stewart F

4 Graham $^{5}$, Irene R Grant ${ }^{1}$, Sunita Grover ${ }^{3}$, Brian D Green ${ }^{1 *}$

$5{ }^{1}$ Institute for Global Food Security, School of Biological Sciences, Queen’s University

6 Belfast, Northern Ireland, UK

$7 \quad$ 2Department of Dairy Microbiology, College of Dairy Science and Technology, Guru Angad

8 Dev Veterinary and Animal Sciences University (GADVASU), Ludhiana, Punjab, INDIA

$9 \quad{ }^{3}$ Molecular Biology Unit, Dairy Microbiology Division, National Dairy Research Institute,

10 Karnal, Haryana, INDIA

$11{ }^{4}$ Agri-Food and Biosciences Institute, Newforge Lane, BT9 5PX, Belfast, Northern Ireland, 12 UK.

$13 \quad{ }^{5}$ Beaumont Research Institute, 3811 W. 13 Road, Royal Oak, MI, 48073, USA.

\# Commonwealth Scholar, Institute for Global Food Security, School of Biological Sciences,

Queen’s University Belfast, Belfast, UK

*Corresponding author: Institute for Global Food Security, School of Biological Sciences,

Queen’s University Belfast, David Keir Building, Stranmillis Road, Belfast, BT9 5AG,

United Kingdom; Email: b.green@qub.ac.uk; Fax: +44289097 6543

Short Title: Lactic acid bacteria modulating incretin hormones. 
22 Abbreviations: GLP-1, glucagon like peptide - 1; GIP, glucose dependent insulinotropic peptide; RIA, radioimmunoassay; EE, enteroendocrine; LAB, lactic acid bacteria.

\section{Abstract}

Glucagon-like peptide-1 (GLP-1) and glucose-dependent insulinotropic polypeptide (GIP) are incretin hormones released from intestinal enteroendocrine (EE) cells and have wellestablished glucose-lowering actions. Lactic acid bacteria (LAB) colonise the human intestine but it is unknown whether LAB and EE cells interact. Acute co-culture of LAB with EE cells showed that certain LAB strains elicit GLP-1 and GIP secretion (13-194-fold) and upregulate their gene expression. LAB-induced incretin hormone secretion did not appear to involve nutrient mechanisms, nor was there any evidence of cytolysis. Instead PCR array studies implicated signalling agents of the toll-like receptor system, e.g. adaptor protein MyD88 was decreased 23-fold and cell surface antigen CD14 was increased 17-fold. Mechanistic studies found that blockade of MyD88 triggered significant GLP-1 secretion.

37 Furthermore, blocking of CD14 completely attenuated LAB-induced secretion. A recent clinical trial clearly shows that LAB have potential for alleviating type 2 diabetes and further characterisation of this bioactivity is warranted.

Keywords: probiotic, lactobacilli, diabetes, incretin hormones, enteroendocrine cells 


\section{Introduction}

The incretin hormones are gastrointestinal insulin-releasing peptides involved in the regulation of postprandial nutrient homeostasis. Postprandial release of these hormones forms part of the entero-insular axis which contributes significantly to normal glucose homeostasis, particularly in the period following the consumption of a meal (Flatt \& Green, 2006; Baggio \& Drucker, 2007; Green et al., 2005). The two established incretin hormones are glucagonlike peptide-1 (GLP-1) and glucose-dependent insulinotropic polypeptide (GIP) and they are produced by enteroendocrine (EE) cells lining the intestine. GLP-1 is produced by intestinal L-cells which are at the highest densities in the distal small intestine and colon. GIP is produced and secreted by K-cells which are predominantly located in the proximal small intestine (Baggio \& Drucker, 2007). It is also evident that EE cells with an L/K phenotype exist and a shift of the intestinal cell population towards this type has been associated with the prevention of beta-cell loss and hyperglycaemia in diabetic animal models (Speck et al., 2011). The incretin hormones have been the basis for a number of clinically approved pharmaceutical compounds with good efficacy for the treatment of human type 2 diabetes and its complications (Neumiller, 2012; Tate et al., 2015]. Importantly their use has been associated with low risk of hypoglycaemia and good tolerability and safety.

A novel and perhaps more radical approach involves the discovery of gut probiotic organisms capable of modulating the incretin hormone system (Yadav et al., 2013; Forssten et al., 2013; Duan, Liu, \& March, 2015). Probiotic bacteria routinely come into close proximity with the intestinal lining allowing the possibility that either they or their bacterial metabolites could stimulate the secretion of incretin hormones from enteroendocrine cells. Lactobacilli are present in the small intestine, although cell densities $\left(10^{4}\right.$ to $\left.10^{8} \mathrm{cfu} / \mathrm{g}\right)$ are lower than in the large intestine $\left(10^{12-14} \mathrm{cfu} / \mathrm{g}\right)$ (Ley, Peterson, \& Gordon, 2006; Walter \& 
Ley, 2011). Gut microbiota are diverse and abundant constituting approximately $10^{14}(100$ trillion) cells in an individual person (Ley, Peterson, \& Gordon, 2006). They contribute significantly to human nutrition and health (Flint et al., 2012) playing roles in immunity (Hardy et al., 2013; Kelly \& Mulder, 2012), the fulfilment of dietary amino acid requirements (Walter \& Ley, 2011) and they impact on energy balance (Molinaro et al., 2012; Cani et al., 2012). Besides these physiological effects, interaction with gut epithelial surface elicits several signalling pathways (Audy et al., 2012; Giahi et al., 2012) that are responsible for regulation of the aforementioned functions. Probiotic-based dietary intervention has been proposed for the alleviation of various clinical conditions including gastrointestinal disorders (Horvath \& Szajewska, 2013; Hijova \& Soltesova, 2013), ulcerative colitis (De Greef et al., 2013; Dylag et al., 2014), necrotizing enterocolitis (Liu et al., 2013), respiratory disorders (Forsythe, 2011) and allergies (Prakash et al., 2013; Castellazzi et al., 2013). The proposed use of probiotics for the alleviation of diabetes and/or obesity is unestablished but is a hotly debated topic (27-29, 9 Sanz, Santacruz, \& Gauffin, 2010; Ejtahed et al., 2012; Panwar et al., 2014; Duan, Liu, \& March, 2015).

The aim of this study was to probe the ability of one genus of lactic acid bacteria (LAB) to modulate the secretion and gene expression of the incretin hormones in EE cells. The strains investigated included Lactobacillus isolates originating from human infant faeces and a number of Lactobacillus reference cultures. For each strain we examined how coculture with pGIP/Neo STC-1 cells affected GLP-1 secretion, GIP secretion, as well as, changes in the expression of proglucagon (the precursor of GLP-1) and GIP genes. The most promising Lactobacillus organism was then used to investigate possible mechanisms through which it exerted effects on EE cells.

\section{Materials and methods}




\subsection{Chemicals and reagents}

De Man, Rogosa and Sharpe (MRS) broth (M369) was obtained from HiMedia Laboratories (Mumbai, India). Mueller-Hinton broth (CM0405) from Oxoid (Hampshire, UK). Dulbecco’s Modified Eagle’s Medium (DMEM) containing 4.5 g/l D-glucose, without sodium pyruvate (GlutaMAX) was obtained from GIBCO, Paisley, UK. Penicillin, streptomycin and geneticin (G418) were purchased from Sigma (Poole, Dorset, UK). Radioiodinated GLP-1 was obtained from Perkin Elmer (Waltham, MA, USA). GIP ELISA kits were purchased from Millipore (Billerica, MA, USA). Cytotoxicity Detection Kit PLUS (LDH) kits were purchased from Roche Diagnostics Ltd (West Sussex, UK).

\subsection{Isolation, culture and Identification of Lactobacillus strains}

Faecal samples were collected from five healthy breast-fed infants $<9$ months in age living in Shamli, Uttar Pradesh, India. In each case parental consent was obtained. Lactobacillus cultures were isolated from faecal samples of healthy human infants (Lb1-15; Table 1). Lactobacillus reference strains (Ref1-7; Table 1) and a Gram positive control (Bifidobacterium bifidum; Ctrl1; Table 1) were obtained from the National Collection of Industrial, Food and Marine Bacteria (Aberdeen, UK). E. coli K12 (Ctrl 2; Table 1) was procured from National Collection of Type Cultures (NCTC) (Colindale, London). Identity of Lactobacillus isolates was determined to genus level by PCR using a genus-specific primer pair (Table 2). Amplified products (Table 2; 1400bp for 16SrRNA and 600bp for Phe) were sequenced using an external DNA sequencing service (DNA Sequencing and Services, University of Dundee, UK).

In preparation for experiments bacterial cultures were grown overnight $\left(37^{\circ} \mathrm{C}\right)$ in their respective media $(10 \mathrm{ml})$, harvested $\left(12,000 \mathrm{~g}, 15 \mathrm{~min}, 10^{\circ} \mathrm{C}\right)$ and washed twice with $1 \mathrm{X}$ PBS. Cell pellets were again re-suspended in $1 \mathrm{X}$ PBS and diluted to O.D600 1.5 which 
corresponded to $1 \times 10^{9} \mathrm{cfu} / \mathrm{mL}$ of viable cells as determined by standard viable count method

117 (Wehr \& Frank, 2004). One millilitre of bacterial culture at O.D600 1.5 was pelleted down and re-suspended in $600 \mu \mathrm{l}$ of freshly prepared HEPES buffer (pH7.4) for co-culture with pGIP/Neo STC-1 cells.

\subsection{Cell Culture}

pGIP/Neo STC-1 cells were a gift from Dr. B. Wice (Washington University of St.

Louis) (Ramshur, Rull, \& Wice, 2002) with permission from Dr D. Hanahan (University of

California, San Francisco, CA). pGIP/Neo STC-1 cells are a GIP enriched sub-clone of heterogeneous pluripotent murine STC-1 cells. The cell line secretes measurable amounts of GLP-1 and GIP, retains secretory function and is responsive to various stimuli (Gillespie et al. 2015; Jafri et al. 2016). Cells were cultured as previously described (Hand, Giblin, \& Green, 2012; Rafferty et al., 2011). Briefly, they were maintained in a humidified incubator at $37^{\circ} \mathrm{C}$ and $5 \% \mathrm{CO}_{2}$ DMEM containing $4.5 \mathrm{~g} / \mathrm{L}$ with L-glutamine, without sodium pyruvate (Life Technologies, Paisley, UK) and supplemented with 10\% foetal bovine serum, 100 $\mathrm{U} / \mathrm{mL}$ penicillin, $100 \mathrm{mg} / \mathrm{L}$ streptomycin and geneticin - G418, $400 \mu \mathrm{g} / \mathrm{mL}$. Cells were trypsinised at 70-80\% confluency and seeded in flasks or plates as required, and only used between 20-50 passages.

Light microscopy of L. rhamnosus and pGIP/Neo STC-1 cells was carried out by fixing with methanol (10 min at room temperature), removing methanol, staining with crystal violet for 30s and washing twice immediately with PBS buffer. Plates were allowed to air dry and viewing using a confocal light microscope (Nikon, Surrey, UK).

\subsection{GLP-1 and GIP secretion studies}


For hormone secretion and gene expression studies approximately $2 \times 10^{6} \mathrm{pGIP} / \mathrm{Neo}$ STC-1 cells were seeded into 12-well plates with DMEM and allowed to attach overnight $\left(37^{\circ} \mathrm{C} ; 5 \% \mathrm{CO}_{2}\right)$, media was removed and cells were washed (3 times; HEPES buffer) (Mccarthy et al., 2015). Cells were pre-incubated in $1 \mathrm{ml}$ of HEPES buffer for $1 \mathrm{~h}$. Buffer was removed and cells were co-cultured with $2 \times 10^{9}$ live bacteria for $3 \mathrm{~h}\left(37^{\circ} \mathrm{C} ; 5 \% \mathrm{CO}_{2}\right)$. Cell supernatant (HEPES Buffer) was aspirated and collected in a fresh tube, placed on ice and centrifuged (5000g, 5 min) to remove any cellular debris. Supernatant was collected and stored at $-70^{\circ} \mathrm{C}$ prior to GLP-1 and GIP immunoassays. mRNA was isolated from cells using a commercial RNeasy Mini Kit (Quigen, Manchester, UK). Additional GLP-1 secretion studies (3h; $37^{\circ} \mathrm{C} ; 5 \% \mathrm{CO}_{2}$ ) were performed with a mixture of L-alanine (20 nmol/L), Lhistidine (20 nmol/L) and L-proline (10 nmol/L). Studies were also conducted with $L$. rhamnosus $\left(2 \times 10^{9} \mathrm{CFU} / \mathrm{mL}\right)$ alone or in combination with either a Myd88 blocking peptide (50 $\mu \mathrm{M}$; Pepinh-MYD, Invivogen, Toulouse, France), or an anti-CD14 antibody (anti-mouse IgG, Cambridge Biosciences, Cambridge, UK). To ensure that hormone measurements were not the result of cytolysis the release of lactate dehydrogenase (LDH) was measured in a series of experiments where, $10^{10}, 10^{9}, 10^{8}, 10^{7}$ or $10^{6} \mathrm{LAB}$ were co-cultured with $2 \times 10^{6}$ pGIP/Neo STC-1 cells for 3h. No cytolysis was detected. GIP concentrations were determined by commercial competitive ELISA kit (Phoenix pharmaceuticals, Inc. California, USA) by following the manufacturer's instructions. GLP-1 concentrations were measured using an in-house fully optimised radioimmunoassay which used anti-rabbit IgG Sac-Cel (IDS, Boldon, UK) and had zero cross-reactivity with glucagon or GIP. GLP-1 and GIP secretion studies were performed in triplicate.

\subsection{Amino acid analysis}


Samples of test buffer $(3 \mathrm{ml})$ were spiked with $0.3 \mathrm{ml}$ Norleucine $(1.5 \mathrm{mg} / \mathrm{ml}$; internal standard) and mixed in $\mathrm{ddH}_{2} \mathrm{O}(10 \mathrm{ml})$ for $1 \mathrm{~min}$. Samples were then centrifuged $(3,500 \mathrm{~g}$, $\left.4^{\circ} \mathrm{C}, 25 \mathrm{~min}\right)$ and the supernatant collected. Pellets were re-suspended in $\mathrm{ddH}_{2} \mathrm{O}(5 \mathrm{ml})$, centrifugation was repeated and both supernatants were combined. The supernatant (500 $\mu \mathrm{l})$ was filtered through a molecular weight cut off filter (Vivaspin, MWCDO 3000, Sigma) with centrifugation at $3,500 \mathrm{~g}$ for $90 \mathrm{~min}$ at $4^{\circ} \mathrm{C}$. The filtered sample $(100 \mu \mathrm{l})$ was analysed using an Agilent GC (model 7890, Delaware, USA) coupled to an MS detector (Agilent model 5975C, Delaware, USA) in combination with an amino acid analysis kit (EZ:faast; Phenomenex, Cheshire, UK).

\subsection{Gene expression studies and real time PCR array}

SYBR green Quantitative real-time PCR was used to determine changes in gene expression with $\beta$-actin used as a reference gene to normalise data. RNA quality and quantity were checked by nanodrop/spectrophotometric (260/280) analysis and gel electrophoresis (1\% agarose), respectively. RNA ( $1 \mu \mathrm{g})$ was converted to cDNA using commercial QuantiTect Reverse Transcription Kit (Qiagen) and was quantified using nanodrop. cDNA was diluted to working dilution of 30ng/ $\mu$ l by dissolving in nuclease free water. Primer sequences for proglucagon (GLP-1), GIP, $\beta$-actin, GPR40, GPR 41 and GPR 120 can be found in Table 2. $\mathrm{RT}^{2}$ Profiler PCR arrays were used to detect the expression of 84 genes implicated in regulating TLR pathways. For PCR array, RNA was further purified using SABiosciences RT² qPCR-Grade RNA Isolation Kit according to the manufacturer’s protocol. RNA quality was analysed and met the required criteria for Real-time PCR arrays. Mouse TLR PCR array kits were purchased from Qiagen (RT Profiler ${ }^{\mathrm{TM}}$ PCR Array Mouse Toll-Like Receptor Signalling Pathway [PAMM-018A-2]). The kit profiles the expression of 84 genes ( $\mathrm{n}=2$ biological replicates) related to TLR-mediated signal transduction and five 
housekeeping genes (GUSB, HPRT1, HSP90ab1, GADPH and ACTB). A negative control for genomic DNA and contaminating RNA was also conducted in each sample. Amplification, data acquisition, and the melting curve were carried out using a Mastercycler ep Realplex (Eppendorf, Stevenage, UK). The PCR cycling program was set as follows: stage 1: $95^{\circ} \mathrm{C}$ for $10 \mathrm{~min}$, stage $2: 95^{\circ} \mathrm{C}$ for $15 \mathrm{sec}$ followed by $60^{\circ} \mathrm{C}$ for 1 minute repeated for 40 cycles, and stage $3: 95^{\circ} \mathrm{C}$ for $15 \mathrm{sec}, 60^{\circ} \mathrm{C}$ for $15 \mathrm{sec}$ and $95^{\circ} \mathrm{C}$ for $15 \mathrm{sec}$. The cycle threshold (Ct) and melting curve of each gene were established and recorded by the software. The delta $\mathrm{Ct}(\Delta \mathrm{Ct})$ method was used for PCR array data analysis. The normalized $\Delta \mathrm{Ct}$ for each gene of interest (GOI) was calculated by deducting the average Ct of the 5 housekeeping genes (HKG) from the $\mathrm{Ct}$ of each gene of interest. Then the double delta $\mathrm{Ct}(\Delta \Delta \mathrm{Ct})$ for each gene of interest was calculated by deducting the average $\Delta \mathrm{Ct}$ in the control group from the $\Delta \mathrm{Ct}$ of each gene of interest. The fold-change of each GOI compared to the sham group was calculated as $2-\Delta \Delta \mathrm{Ct}$.

\subsection{Data analysis}

Graphs were produced and statistically analysed using Graph pad Prism (Version 6, La Jolla, CA, USA). Bar graphs display mean \pm SEM. A heat map of PCR array data was generated (MetATT) which employed mean centred data normalisation.

\section{Results}

\subsection{GLP-1 and GIP secretion following Lactobacillus co-culture}

Co-culture of a number of Lactobacillus strains with pGIP/Neo STC-1 cells elicited significant GLP-1 secretion which was not associated with cytotoxicity or cytolysis. Cells incubated in a non-stimulatory vehicle control secreted $4.5 \pm 0.5 \mathrm{pM} / 10^{6}$ cells/h whereas $3 \mathrm{~h}$ co-culture with faecal isolate, Lb3 (later identified as Lactobacillus plantarum subsp. 
argentorotensis; KC491380) secreted $86.8 \pm 6$ pM/10 $10^{6}$ cells/h (Figure 1A). For GIP, secretion of $1.9 \pm 0.05 \mathrm{pM} / 10^{6}$ cells/h occurred with a non-stimulatory vehicle control. Two faecal isolate strains: Lb1 (later identified as being Lactobacillus plantarum) and Lb3 stimulated significant GIP secretion (Figure 1B; $100.6 \pm 2.9$ and $155.8 \pm 24.9$ pM/106 cells/h, respectively. Co-culture with two reference strains L. johnsonii (NCIMB8795) and L. rhamnosus (NCIMB6375) significantly increased both GLP-1 secretion (Figure 1A; 61.0 \pm 8.4 and 82.3 $\pm 26.1 \mathrm{pM} / 10^{6}$ cells/h, respectively) and GIP secretion (Figure 1B; $369.5 \pm 68.9$ and $285.7 \pm 34.7 \mathrm{pM} / 10^{6}$ cells/h, respectively). The Gram positive (B. bifidum) and Gram negative (E. coli) control organisms did not stimulate any incretin hormone secretion.

\subsection{Changes in incretin hormone gene expression following Lactobacillus co-culture}

A number of Lactobacillus strains affected the levels of gene expression of proglucagon and GIP in pGIP/Neo STC-1cells. Two Lactobacillus isolates Lb4 and Lb6 (both identified as Lactobacillus plantarum) upregulated proglucagon gene expression 3.6and 2.5-fold, respectively (Figure 2A). Four reference strains L. acidophilus (NCIMB701748), L. casei (NCIMB4114), L. plantarum (NCIMB1406) and L. rhamnosus (NCIMB6375) significantly increased proglucagon gene expression (Figure 2A; 2.9-, 1.8-, 1.9- and 2.9-fold, respectively). Interestingly, B. bifidum up-regulated GLP-1 proglucagon gene expression 2.1-fold. Four Lactobacillus isolates Lb4, Lb6, Lb8 and Lb9 (all Lactobacillus plantarum) along with three reference cultures (L. casei, L. plantarum and L. rhamnosus) significantly up-regulated GIP gene expression (Figure 2B; 2.5-, 2.7-, 2.3, 2.2-, 2.4-, 3.2- and 5.4-fold, respectively). The Gram-negative bacterium E. coli did not affect either proglucagon or GIP gene expression.

\subsection{Nutrient-related mechanisms involved in Lactobacilli-stimulated GLP-1 secretion}


rhamnosus was selected for further studies. Changes in the amino acid composition of the test

buffer were examined by GC-MS (Figure 3A) which indicated that there was a significant increase in the levels of L-alanine, L-proline and L-Histidine. However, a combination of these three amino acids failed to stimulate GLP-1 secretion in STC-1pGIP/Neo cells (Figure receptors (GPR40, 41 and 120) were examined. These were compared against $L$. casei, which did not stimulate incretin hormone secretion but did alter incretin gene expression. $L$. rhamnosus modestly increased the expression of GPR40 (2.4 \pm 1.4 -fold) and decreased GPR120 (0.4 \pm 0.01 -fold) and had no effect on GPR41. By comparison L. casei upregulated GPR-40 by $6.7 \pm 1$ and GPR-41 by $28.0 \pm 4$ fold and left GPR120 unchanged. The isolate Lb-3 was also examined (data not shown) and it did not affect the expression of any of the three FFA receptors.

\subsection{Molecular mechanisms involved in Lactobacilli-stimulated GLP-1 secretion} Confocal light microscopy (Figure 4A) demonstrated that L. rhamnosus cells (purple) are closely localised to pGIP/Neo STC-1 cells (blue), perhaps even adhering to the cell surface. A mouse PCR array examined the effect of $L$. rhamnosus co-culture on the expression of 84 genes related to Toll-like receptor signalling pathways (Figure 4B). A full list of the genes affected can be found in Supplementary Table 1. Whilst up-regulation in the expression of some genes was evident the majority were down-regulated following $L$. rhamnosus co-culture (Figure 4B). Some of the most profound changes in expression occurred in genes identified as “Adaptors \& Interacting Proteins” (Supplementary Table 1). Most notably CD14 expression was up-regulated most (17.5-fold) and Myd88 was downregulated greatest (23.4-fold). The application of the MyD88 blocking peptide (Pepinh- 
MYD) alone evoked a significant GLP-1 secretory response (Figure 4C; 2.3-fold; $\mathrm{P}<0.001$ ),

257

258

259

260

261

262

263

264

265

266

267

268

269

270

271

272

273

274

275 but Pepinh-MYD did not significantly affect L. rhamnosus-stimulated GLP-1 secretion. No GLP-1 secretory responses were evident when an antibody directed against the cell surface antigen CD14 (anti-CD14) was applied alone or in combination with L. rhamnosus (Figure 4C).

\section{Discussion}

This study is the first to demonstrate that lactic acid bacteria can interact with physiologically important intestinal cells. The EE cells collectively constitute the largest endocrine system in the body, producing and secrete a range of different gastrointestinal hormones. Co-culturing of EE cells with various Lactobacillus strains/isolates clearly affected the extent to which the cells secrete and express the incretin hormones. We have identified novel bacterial isolates which modulate the secretion and expression of both GLP-1 and GIP. For example L. plantarum subsp. argentorotensis (Lb3) which triggered potent GLP-1 and GIP secretion in pGIP/Neo STC-1 cells. Various isolates identified as strains of $L$. plantarum (i.e. Lb1, 4, 6, 8, and 9), along with the corresponding reference culture (Ref6), positively influenced either incretin hormone secretion or incretin gene expression (but not both simultaneously). 16S rRNA sequencing revealed none of the L. plantarum isolates to be genetically identical, which may explain why their effects on EE cells were inconsistent. Indeed there were some L. plantarum isolates (e.g. Lb2, Lb5) which had no impact on incretin secretion or expression.

There were similar observations with L. acidophilus where the isolate Lb15 had no appreciable effects, yet the corresponding reference culture (Ref 1) significantly up-regulated proglucagon gene expression. The reference culture of L. johnsonii showed particularly promising effects on incretin hormone secretion but did not affect gene expression. Only the 
reference culture of $L$. rhamnosus positively influenced all four incretin hormone parameters which prompted us to select it for further investigation. It is well established that incretin hormone secretion can be stimulated by the presence of either amino acids or fatty acids in the lumen of the intestine (Baggio \& Drucker, 2007). Therefore, we examined whether $L$. rhamnosus was influencing GLP-1 secretion through a nutrient-based mechanism. The bacterial metabolism of $L$. rhamnosus appeared to elevate the levels of three amino acids (Lalanine, L-proline and L-histidine) in the test buffer, yet when tested these amino acids did not stimulate GLP-1 secretion. It is well known that Lactobacillus spp. (including $L$. rhamnosus) can produce various fatty acids, most notably short-chain fatty acids (SCFAs) such as butyrate (Umeki et al., 2004; Licciardi et al., 2010). Fatty acids are known to be secretagogues of GLP-1 and GIP. We found that FFA receptor expression (GPR40, 41 and 120) in EE cells was affected by co-culture with lactobacilli. L. rhamnosus modestly increased mRNA transcripts of one medium/long chain FFA receptor (GPR40) but reduced that of another medium/long chain FFA receptor (GPR120). However, it was clear that $L$. rhamnosus did not affect the expression of the SCFA receptor GPR41 and when measured the levels of butyrate in the culture medium were unaffected (data not shown) indicating that production of SCFAs was unlikely to be responsible for observed effects on EE cells. There is a potential limitation in this study - that changes in other FA receptors expressed on enteroendocrine cells (such as GPR119 for example) were not examined. A role for medium/long chain fatty acids cannot be completely ruled out, however, it is clear that $L$. casei (which is devoid of incretin secretory activity) had more profound effects than $L$. rhamnosus on FFA receptor expression (i.e. GPR40 and 41).

In a separate phase of studies we attempted to ascertain whether L. rhamnosus could be influencing GLP-1 secretion through its direct interaction with the EE cell surface. This 
was prompted by the observation that in co-culture the majority of L. rhamnosus cells closely co-localise with pGIP/Neo STC-1 cells, even when cells were seeded at lower densities. We thought that the most logical mechanism for a bacterial-mammalian cell interaction was through the toll-like receptor (TLR) family of pattern recognition receptors which detect a wide range of exogenous factors including bacteria, viruses, fungi and parasites (Kamdar, Nguyen, \& DePaolo, 2013). A qPCR array measuring the expression of 84 TLR-related genes (See Supplementary Table 1) was performed. This produced quite startling results - there was a broad (but not exclusive) down-regulation of the genes in the TLR family, some of which were reduced by more than 20-fold. TLR2 and TLR4 receptors were significantly downregulated, but some of the biggest changes were in the expression of adaptor proteins involved in TLR signalling. These included the cell surface antigen CD14 which was increased almost 18-fold and the adapter protein MyD88 which was decreased 23-fold.

These two proteins were tentatively investigated for their potential involvement in $L$. rhamnosus-induced stimulation of GLP-1 secretion. Interestingly, we found that the addition of pepinh-MYD (which blocks the homo-dimerisation of MyD88) alone caused significant GLP-1 secretion. Importantly pepinh-MYD did not have an additive effect on L. rhamnosusinduced GLP-1 secretion. This finding suggests that down-regulation of MyD88 expression/activity leads to higher levels of GLP-1 secretion, although it cannot be definitively stated that this is the precise mechanism for L. rhamnosus-stimulated GLP-1 secretion. We also found that the application of an antibody directed against murine CD14 alone had no effect on GLP-1 secretion but it significantly attenuated L. rhamnosusstimulated secretion. CD14 plays a key role in initiating cell activation by a range of bacterially-derived molecules, such as the lipopolysaccharides from Gram-negative bacteria and peptidoglycans from Gram-positive and Gram-negative bacteria (Dziarski, Tapping, \& 
328 Tobias, 1998). It could be postulated that CD14 is a surface antigen which facilitates 329 adhesion of $L$. rhamnosus peptidoglycans to the EE cell surface, but the exact signalling role 330 (if any) for eliciting incretin hormone secretion clearly requires further investigation. CD14 is 331 best characterised as a feature of monocytes and macrophages with most subpopulations of 332 these cells expressing CD14. The interaction of commensal bacteria with the gut lining is an incredibly understudied area and there is presently very little scientific literature elucidating the role of CD14 in the intestine. It ha s been shown however, that an E. coli probiotic organisms used in the treatment of inflammatory bowel disorders stimulated the gene expression of CD14 in the Caco-2 intestinal epithelial cell line (Hafez et al., 2010). Although this study did also report that the expression of the adaptor molecules MyD88 and Ticam1 Currently, the investigation of the functional and physiological actions of probiotics is an extremely active research field, and many health benefits are proposed including the improvement of gastrointestinal function and lowering of blood cholesterol levels (Macfarlane \& Cummings, 1999). Their incorporation into fermented and non-fermented dairy products is well accepted, and their inclusion in functional foods such as e.g. fruit juices, breakfast cereals, cereal bars, etc. has also been investigated. There is growing support for the concept of utilising probiotic organisms as a dietary prophylactic or therapeutic strategy for type 2 diabetes mellitus (Yadav et al. 2013; Panwar et al., 2014; Panwar et al., 2016). The concept has been demonstrated in a recent clinical trial which found that administration of the probiotic $L$. reuteri increased insulin secretion and incretin release in humans (Simon et al., 2015). This group concluded that since L. reuteri did not modulate faecal microbiota it is likely that Lactobacillus spp. have a direct effect on host physiology a proposition which this study supports. 
353 In conclusion, this study has shown that there is considerable potential to increase 354 endogenous GLP-1 and GIP secretion using naturally-occurring commensal bacteria. Our 355 findings demonstrate that there are cell-to-cell interactions between human commensal 356 bacterial and EE cells, and that the adaptor proteins of the TLR system are one plausible 357 signalling mechanism. The underlying protein interactions of specific Lactobacilli with EE 358 cells should be investigated including the profound changes observed in MyD88 and CD14 359 expression. The precise role of these proteins in triggering LAB-induced secretion needs to 360 be elucidated. A limitation of the study is that it focused only on Lactobacillus spp. and the contribution of the many other species of commensal bacteria needs to be investigated. Probiotic organisms represent a novel therapeutic strategy for type 2 diabetes but it will be necessary to undertake dietary intervention studies involving safe, well-characterised and commercially available probiotic stains.

\section{Conflict of interest}

The authors have no conflicts of interest to declare.

\section{Acknowledgements}

368 Authors would like to acknowledge funding from Commonwealth Scholarship Commission,

369 UK as part of PhD studentship to Harsh Panwar tenable at Queen’s University Belfast (UK).

370 Author Contributions: Harsh Panwar designed the experiments, analysed and interpreted

371 the data and drafted the manuscript. Danielle Calderwood, Alastair Wylie, Sunita Grover and

372 Stewart Graham designed experiments, analysed and interpreted the data. Brian Green and

373 Irene Grant conceived the study, designed the experiments, analysed and interpreted the data, 
374 and drafted the manuscript. All authors approved the final version of the manuscript to be 375 published. 


\section{References}

378

379

380

381

382

383

384

385

386

387

388

Audy, J., Mathieu, O., Belvis, J., \& Tompkins, T. A. (2012). Transcriptomic response of immune signalling pathways in intestinal epithelial cells exposed to lipopolysaccharides, Gram-negative bacteria or potentially probiotic microbes. Beneficial Microbes, 3(4), 273-86.

Baggio, L. L., \& Drucker, D. J. (2007). Biology of incretins: GLP-1 and GIP. Gastroenterology, 132(6), 2131-2157.

Brown, A. J., Goldsworthy, S. M., Barnes, A. A., Eilert, M. M., Tcheang, L., Daniels, D., Muir, A. I., Wigglesworth, M. J., Kinghorn, I., Fraser, N. J., Pike, N. B., Strum, J. C., Steplewski, K. M., Murdock, P. R., Holder, J. C., Marshall, F. H., Szekeres, P. G., Wilson, S., Ignar, D. M., Foord, S. M., Wise, A., Dowell, S. J. (2003). The Orphan G Protein-coupled Receptors GPR41 and GPR43 are activated by propionate and other short chain carboxylic acids. The Journal of Biological Chemistry, 278(13), 11312-11319.

Cani, P. D., Osto, M., Geurts, L., \& Everard, A. (2012). Involvement of gut microbiota in the development of low-grade inflammation and type 2 diabetes associated with obesity. Gut Microbes, 3(4), 279-288.

Castellazzi, A. M., Valsecchi, C., Caimmi, S., Licari, A., Marseglia, A., Leoni, M. C., Caimmi, D., Miraglia del Giudice, M., Leonardi, S., La Rosa, M., \& Marseglia, G. L. (2013). Probiotics and food allergy. Italian Journal of Pediatrics, 39(47), 1-10.

De Greef, E., Vandenplas, Y., Hauser, B., Devreker, T., \& Veereman-Wauters, G. (2013). Probiotics and IBD. Acta Gastro-Enterologica Belgica, 76, 15-19. 
Duan, F. F., Liu, J. H., \& March, J. C. (2015). Engineered commensal bacteria reprogram intestinal cells into glucose-responsive insulin-secreting cells for the treatment of diabetes. Diabetes, 1-10. Doi:10.2337/db14-0635.

Dubernet, S., Desmasures, N., \& Gueguen, M. (2002). A PCR based method for identification of lactobacilli at the genus level. FEMS Microbiology Letters, 214(2), 271-275.

Dylag, K., Hubalewska-Mazgaj, M., Surmiak, M., Szmyd, J., \& Brzozowski, T. (2014). Probiotics in the mechanism of protection against gut inflammation and therapy of gastrointestinal disorders. Current Pharmaceutical Design, 20(18), 1149-1155.

Dziarski, R., Tapping, R. I., \& Tobias, P. S. (1998). Binding of bacterial peptidoglycan to CD14. The Journal of Biological Chemistry 273(15), 8680-8690.

Ejtahed, H. S., Mohtadi-Nia, J., Homayouni-Rad, A., Niafar, M., Asghari-Jafarabadi, M., \& Mofid, V. (2012). Probiotic yogurt improves antioxidant status in type 2 diabetic patients. Nutrition, 28(5), 539-543.

Flatt, P. R., \& Green, B. D. (2006). Nutrient regulation of pancreatic beta cell function in diabetes problems and potential solutions. Biochemical Society Transactions, 34(5), 774-778.

Flint, H. J., Scott, K. P., Louis, P., \& Duncan, S. H. (2012). The role of the gut microbiota in nutrition and health. Nat. Rev. Journal of Gastroenterology and Hepatology, 9(10), 577-589.

Forssten, S. D., Korczynska, M. Z., Zwijsen, R. M. L., Noordman, W. H., Madetoja, M., \& Ouwehand, A.C. (2013). Changes in satiety hormone concentrations and feed intake in rats in response to lactic acid bacteria. Appetite, 71, 16-21. 
423 Forsythe, P. (2011). Probiotics and lung diseases. Chest, 139(4), 901-908.

424 Giahi, L., Aumueller, E., Elmadfa, I., \& Haslberger, A. G. (2012). Regulation of TLR4, p38

425

426

427 MAP kinase, I $\mathrm{B}$ and miRNAs by inactivated strains of lactobacilli in human dendritic cells. Beneficial Microbes, 3(2), 91-98.

Gillespie, A.L., Calderwood, D., Hobson, L., Green, B. D. (2015). Whey proteins have beneficial effects on intestinal enteroendocrine cells stimulating cell growth and increasing the production and secretion of incretin hormones. Food Chemistry 189:1208.

Green, B. D., Gault, V. A., O’Harte, F. P. M., \& Flatt, P. R. (2005). Development and therapeutic potential of incretin hormone analogues for type 2 diabetes. The British Journal of Diabetes \& Vascular Disease, 5, 134-140.

Hafez, M., Hayes, K., Goldrick, M., Grencis, R. K., \& Roberts, I. S. (2010). The K5 capsule of Escherichia coli strain Nissle 1917 is important in stimulating expression of Toll like receptor 5, CD14, MyD88, and TRIF together with the induction of interleukin-8 expression via the mitogen-activated protein kinase pathway in epithelial cells. Infection and Immunity 78, 2153-2162.

Hand, K. V., Giblin, L. \& Green, B. D. (2012). Hormone profiling in a novel enteroendocrine cell line pGIP/neo: STC-1. Metabolism, 61(12), 1683-1686.

Hardy, H., Harris, J., Lyon, E., Beal, J., \& Foey, A. D. (2013). Probiotics, prebiotics and immunomodulation of gut mucosal defences: homeostasis and immunopathology. Nutrients, 5(6), 1869-1912.

Hijova, E., \& Soltesova, A. (2013). Effects of probiotics and prebiotics in ulcerative colitis. Bratislava Medical Journal, 114(9), 540-543. 
446 Horvath, A., \& Szajewska, H. (2013). Probiotics, prebiotics, and dietary fiber in the management of functional gastrointestinal disorders. World Review of Nutrition and Dietetics, 108, 40-48.

449

450

451

452

453

454

455

456

457

458

459

460

461

462

463

464

465

466

467

Jepeal, L. I., Boylan, M. O., \& Wolfe, M. M. (2008). GATA-4 upregulates glucose dependent insulinotropic polypeptide expression in cells of pancreatic and intestinal lineage. Molecular and Cellular Endocrinology, 287(1-2), 20-29.

Kamdar, K., Nguyen, V., \& DePaolo, R. W. (2013). Toll-like receptor signaling and regulation of intestinal immunity. Virulence, 4(3), 207-212.

Katsuma, S., Hatae, N., Yano, T., Ruike, Y., Kimura, M., Hirasawa, A., \& Tsugimoto, G. (2005). Free fatty acids inhibit serum deprivation-induced apoptosis through GPR120 in a murine enteroendocrine cell line STC-1. The Journal of Biological Chemistry, 280, 19507-19515.

Kelly, D., \& Mulder, I. E. (2012). Microbiome and immunological interactions. Nutrition Reviews, 70, S18-830.

Ley, R. E., Peterson, D. A., \& Gordon, J. I. (2006). Ecological and evolutionary forces shaping microbial diversity in the human intestine. Cell, 124(4), 837-848.

Licciardi, P. V., Wong, S. S., Tang, M. L., \& Karagiannis, T. C. (2010). Epigenome targeting by probiotic metabolites. Gut Pathogens, 2(1), 24.

Liu, Y., Fatheree, N. Y., Dingle, B. M., Tran, D. Q., \& Rhoads, J. M. (2013). Lactobacillus reuteri DSM 17938 changes the frequency of Foxp3+ regulatory $\mathrm{T}$ cells in the intestine and mesenteric lymph node in experimental necrotizing enterocolitis. PLoS One. 8(12), e56547. 
Mccarthy, T., Green, B. D., Calderwood, D., Gillespie, A., Cryan, J. F., Giblin, L. (2015). STC-1 cells in Verhoeckx, K., Cotter, P., Lopez-Exposito, I., Kleiveland, C., Lea, T. (Ed.), The Impact of Food Bioactives on Health In Vitro and Ex Vivo Models: 211220.

Macfarlane G.T., Cummings J.H. (1999). Probiotics and prebiotics: Can regulating the activities of intestinal bacteria benefit health? British Medical Journal. 318(7189), 999-1003.

Molinaro, F., Paschetta, E., Cassader, M., Gambino, R., \& Musso, G. (2012). Probiotics, prebiotics, energy balance, and obesity: mechanistic insights and therapeutic implications. Gastroenterology Clinics of North America, 41(4), 843-854.

Naser, S. M., Dawyndt, P., Hoste, B., Gevers, D., Vandemeulebroecke, K., Cleenwerck, I., Vancanneyt, M., Swings, J. (2007). Identification of lactobacilli by pheS and rpoA gene sequence analyses. International Journal of Systematic and Evolutionary Microbiology, 57(12), 2777-2789.

Neumiller, J. J. (2012). Incretin pharmacology: a review of the incretin effect and current incretin-based therapies. Cardiovascular \& Hematological Agents in Medicinal chemistry, 10(4), 276-288.

Panwar, H., Calderwood, D., Grant, I. R., Grover, S., \& Green, B. D. (2014). Lactobacillus strains isolated from infant faeces possess potent inhibitory activity against intestinal alpha- and beta-glucosidases suggesting anti-diabetic potential. European Journal of Nutrition, 53(7), 1465-1474.

Panwar, H., Calderwood, D., Grant, I. R., Grover, S., \& Green, B. D. (2016). Lactobacilli possess inhibitory activity against dipeptidyl peptidase-4 (DPP-4). Annals of Microbiology 66(1), 505-509. 
Prakash, S., Tomaro-Duchesneau, C., Saha, S., Rodes, L., Kahouli, I., Malhotra M. (2013). Probiotics for the prevention and treatment of allergies, with an emphasis on mode of delivery and mechanism of action. Current Pharmaceutical Design, 20(6), 1025-1037.

Rafferty, E. P., Wylie, A. R., Hand, K. H., Elliott, C. E., Grieve, D. J., Green, B. D. (2011). Investigating the effects of physiological bile acids on GLP-1 secretion and glucose tolerance in normal and GLP-1 R(-/-) mice. The Journal of Biological Chemistry, 392(6), 539-546.

Ramshur, E. B., Rull, T. R., \& Wice, B. M. (2002). Novel insulin/GIP co-producing cell lines provide unexpected insights into gut K-cell function in vivo. Journal of Cellular Physiology, 192(3), 339-350.

Rasouli, M., Ahmad, Z., Omar, A. R., \& Allaudin, Z. N. (2011). Engineering an L-cell line that expresses insulin under the control of the glucagon-like peptide- 1 promoter for diabetes treatment. BMC Biotechnology, 11(99), 1-8.

Rogall, T. J., Wolters, T. F., \& Bottger, E. C. (1990). Towards a phylogeny and definition of species at the molecular level within the genus Mycobacterium. International Journal of Systematic Bacteriology, 40, 323-330.

Sanz, Y., Santacruz, A., \& Gauffin, P. (2010). Gut microbiota in obesity and metabolic disorders. Proceedings of the Nutrition Society, 69(3), 434-441.

Simon, M. C., Strassburger, K., Nowotny, B., Kolb, H., Nowotny, P., Burkart, V., Zivehe, F., Hwang, J. H., Stehle, P., Pacini, G., Hartmann, B., Holst, J. J., MacKenzie, C., Bindels, L. B., Martinez, I., Walter, J., Henrich, B., Schloot, N. C., Roden, M. (2015). Intake of Lactobacillus reuteri Improves incretin and insulin secretion in glucose 
tolerant humans: a proof of concept. Diabetes Care, pii: dc142690. [Epub ahead of print]

Speck, M., Cho, Y. M., Asadi, A., Rubino, F., \& Kieffer, T. J. (2011). Duodenal-jejunal bypass protects GK rats from \{beta\}-cell loss and aggravation of hyperglycemia and increases enteroendocrine cells coexpressing GIP and GLP-1. American Journal of Physiology. Endocrinology and metabolism, 300(5), E923-932.

Tate, M., Chong, A., Robinson, E., Green, B. D., \& Grieve, D. J. (2015). Selective targeting of glucagon-like peptide-1 signalling as a novel therapeutic approach for cardiovascular disease in diabetes. British Journal of Pharmacology, 172(3), 721-736.

Turner, S., Pryer, K. M., Miao, V. P. W., \& Palmer, J. D. (1999). Investigating deep phylogenetic relationships among cyanobacteria and plastids by small subunit rRNA sequence analysis. Journal of Eukaryotic Microbiology, 46(4), 327-338.

Umeki, U., Oue, K., Mochizuki, S., Shirai, Y., \& Sakai, K. (2004). Effect of Lactobacillus rhamnosus KY-3 and cellobiose as synbiotics on lipid metabolism in rats. Journal of Nutritional Science and Vitaminology, 50(5), 330-334.

Walter, J., \& Ley, R. (2011). The human gut microbiome: Ecology and recent evolutionary changes. Annual Review of Microbiology, 65, 411-429.

Wehr, H. M., \& Frank, J. F. (Eds.) (2004). Standard Methods for the Examination of Dairy Products, American Public Health Association, Baltimore, United States of America 2004.

Yadav, H., Lee, J. H., Lloyd, J., Walter, P., \& Rane, S. G. (2013). Beneficial metabolic effects of a probiotic via butyrate-induced GLP-1 hormone secretion. The Journal of Biological Chemistry, 288(35), 25088-25097. 
Figure 1 Co-culture of enteroendocrine cells with Lactobacillus strains stimulates incretin hormone secretion. Graphs show effects of 15 Lactobacillus isolates (Lb1-15), 7

Lactobacillus reference cultures, a Gram positive control (B. bifidum) and a Gram negative following 3h co-culture. Data represent means \pm SEM ( $n=6)$ and statistical significance is indicated ( ${ }^{*} \mathrm{P}<0.05$ and $* * * \mathrm{P}<0.001$ compared with control; One-way ANOVA).

Figure 2 Co-culture of enteroendocrine cells with Lactobacillus strains upregulates incretin hormone gene expression. Graphs show effects of 15 Lactobacillus isolates (Lb115), 7 Lactobacillus reference cultures, a Gram positive control (B. bifidum) and a Gram negative control (E. coli) on the gene expression of (A) proglucagon (the precursor for GLP1) and (B) GIP in pGIP/Neo STC-1 cells following 3h co-culture. Data represent means \pm SEM ( $\mathrm{n}=6)$ and statistical significance is indicated ( ${ }^{* *} \mathrm{P}<0.01$ and $* * * \mathrm{P}<0.001$ compared with control; One-way ANOVA).

Figure 3 Possible metabolite-based mechanisms responsible for Lactobacillus-stimulated incretin hormone secretion. L. rhamnosus was selected for further studies due to its ability to potently stimulate both GLP-1 and GIP secretion. (A) Changes in amino acid composition of buffer were identified by GC-MS. (B) Exposure of pGIP/Neo STC-1 cells with the 3 elevated amino acids (alanine, histidine and proline) did not influence GLP-1 secretion. (C) 
co-culture and compared against vehicle control and L. casei (a Lactobacillus strain which did not stimulate incretin hormone secretion but did influence incretin gene expression. Data represent means \pm SEM $(n=3)$ and statistical significance is indicated $\left({ }^{*} \mathrm{P}<0.05\right.$ and *** $\mathrm{P}<0.001$ compared with control; ns- not significant; One-way ANOVA).

Figure 4 Other molecular mechanisms possibly involved Lactobacillus-stimulated incretin hormone secretion. (A) Confocal light microscopy (x400) indicated that many L.rhamnosus organisms (black) are closely localised to pGIP/Neo STC-1 cells (blue), perhaps adhering to the cell surface. (B) Toll-like receptor signalling pathways were probed using a mouse TLR PCR array which demonstrated that a large number of these genes were downregulated following L rhamnosus co-culture (also see Supplementary Table 1). CD14 expression was up-regulated most (17.5-fold) and Myd88 was down-regulated most (23.4fold). (C) Application of a My88 blocking peptide or an antibody directed against the cell surface antigen CD14 significantly affected GLP-1 secretion. Data represent means \pm SEM (n=3) with $* \mathrm{P}<0.05$ and $* * * \mathrm{P}<0.001$ compared with control; ${ }^{\Delta \Lambda} \mathrm{P}<0.01 ;{ }^{\Delta \Lambda} \mathrm{P}<0.001$ compared with L.rhamnosus; One-way ANOVA). 

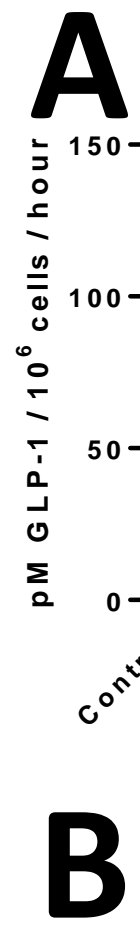

G LP-1 secretion

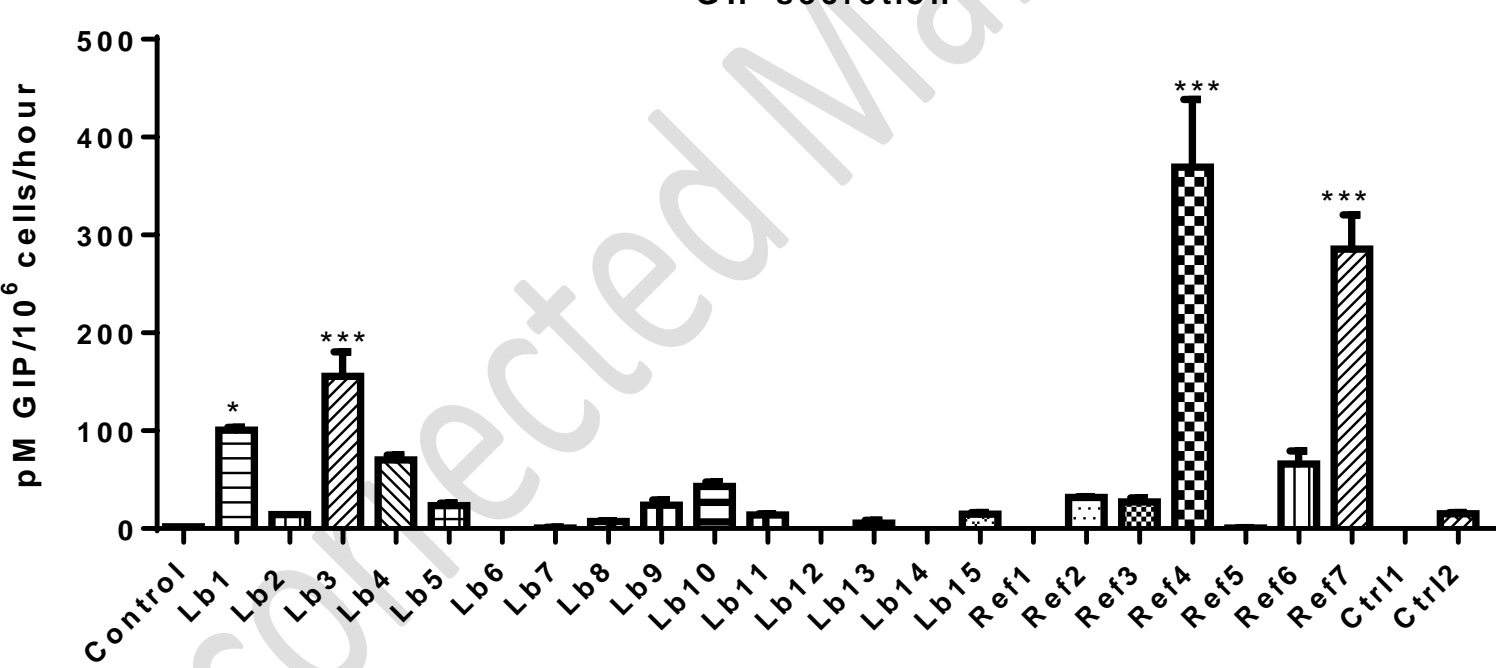


$580 \quad$ Figure 2

A

5 Proglucagongene expression

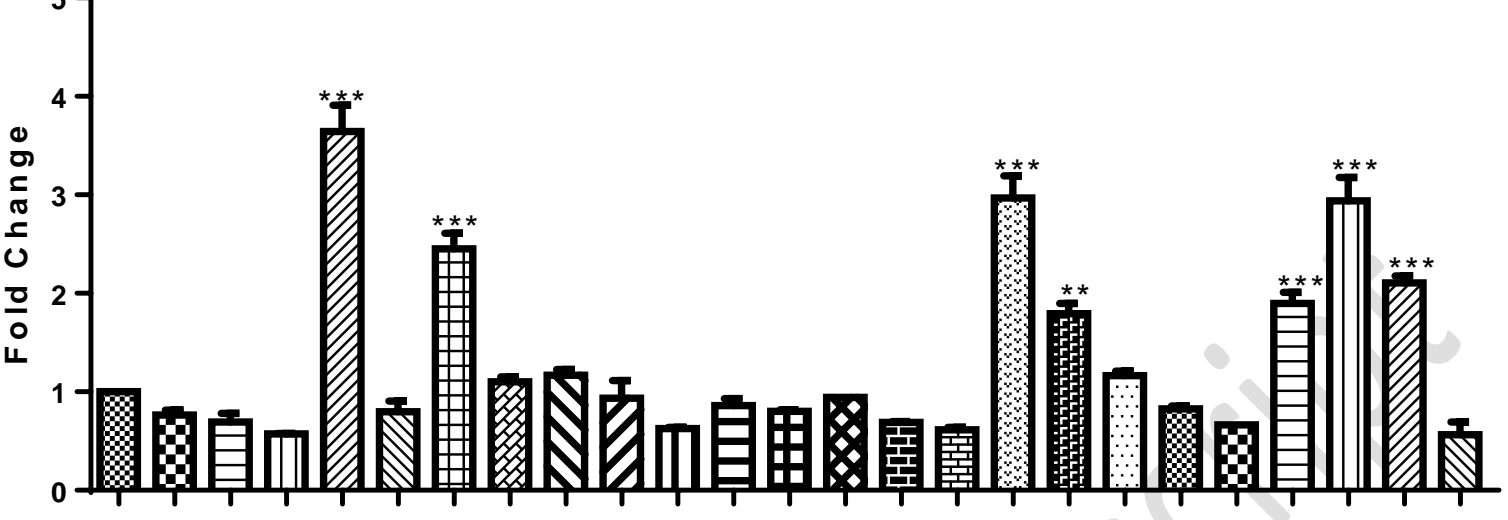

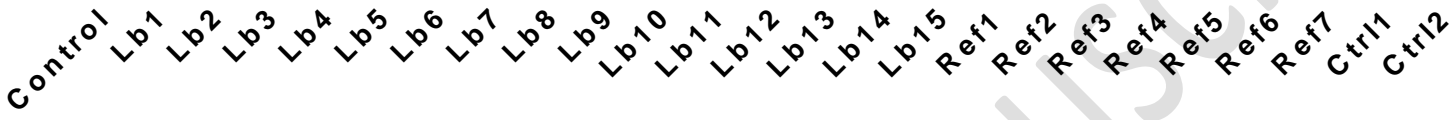

B

8 GIP gene expression

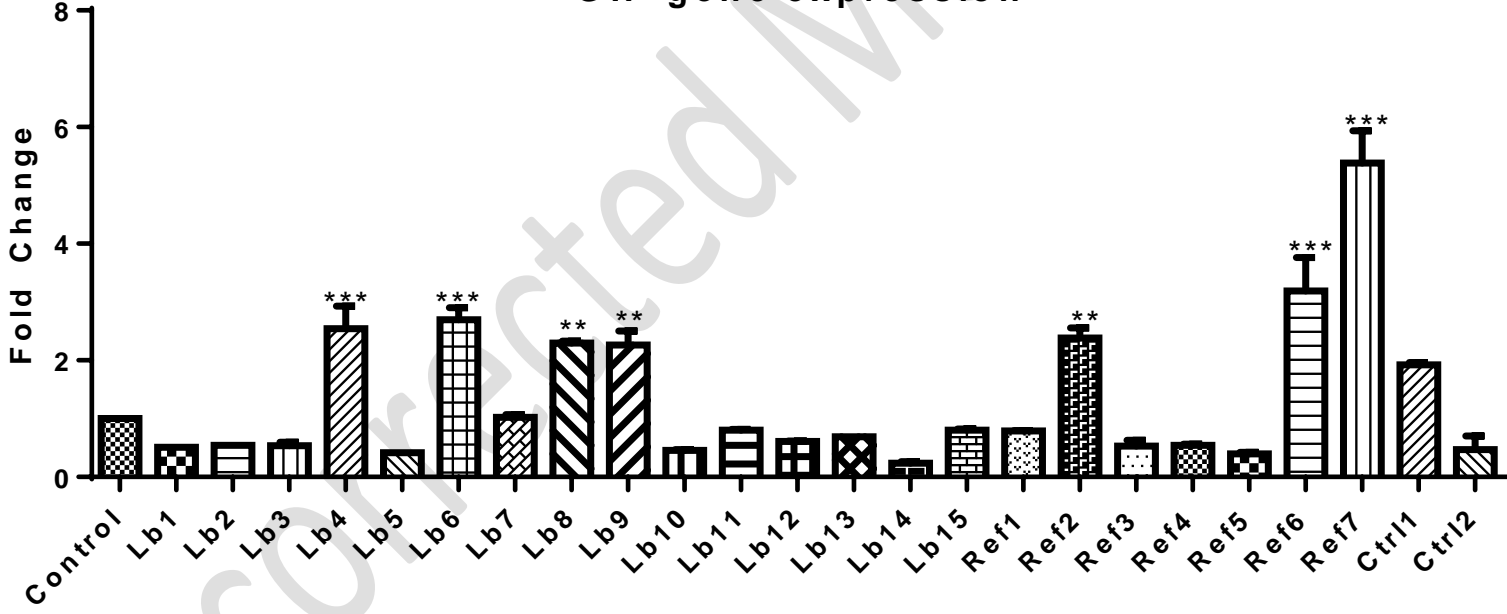




\section{Figure 3}

A

B

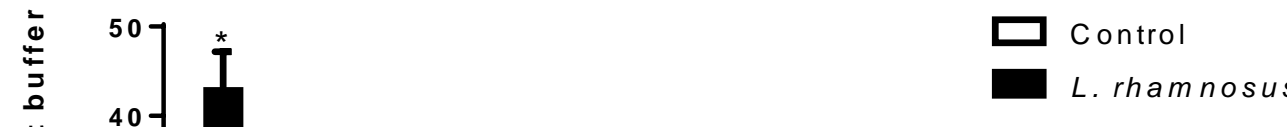

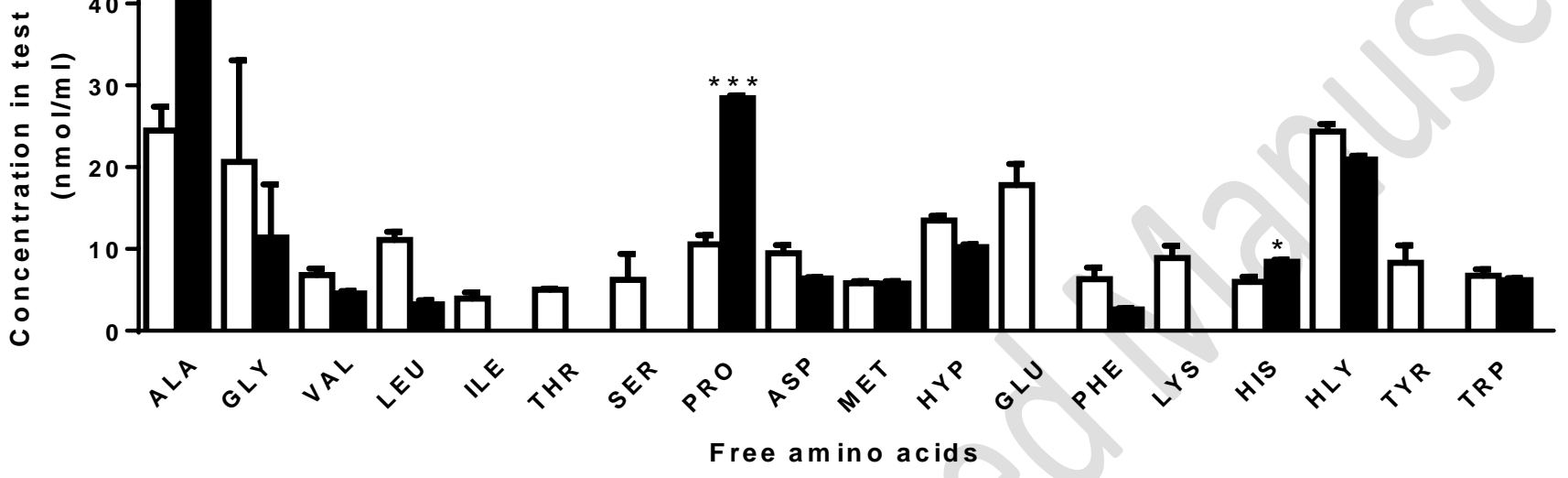

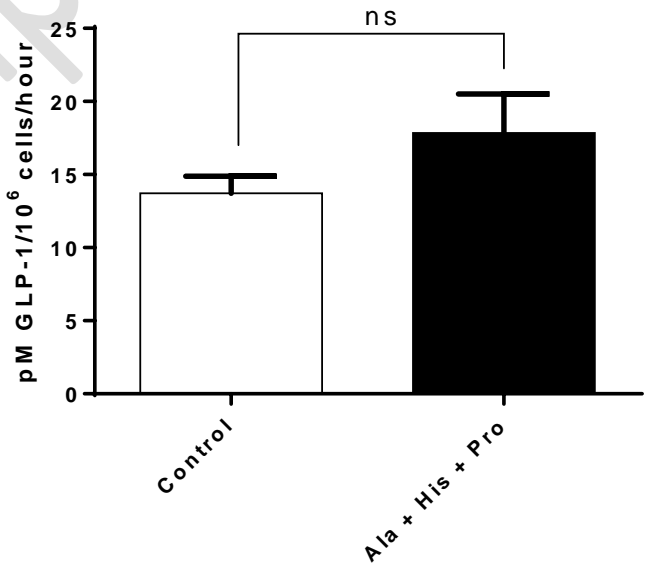

c

D $E$ 

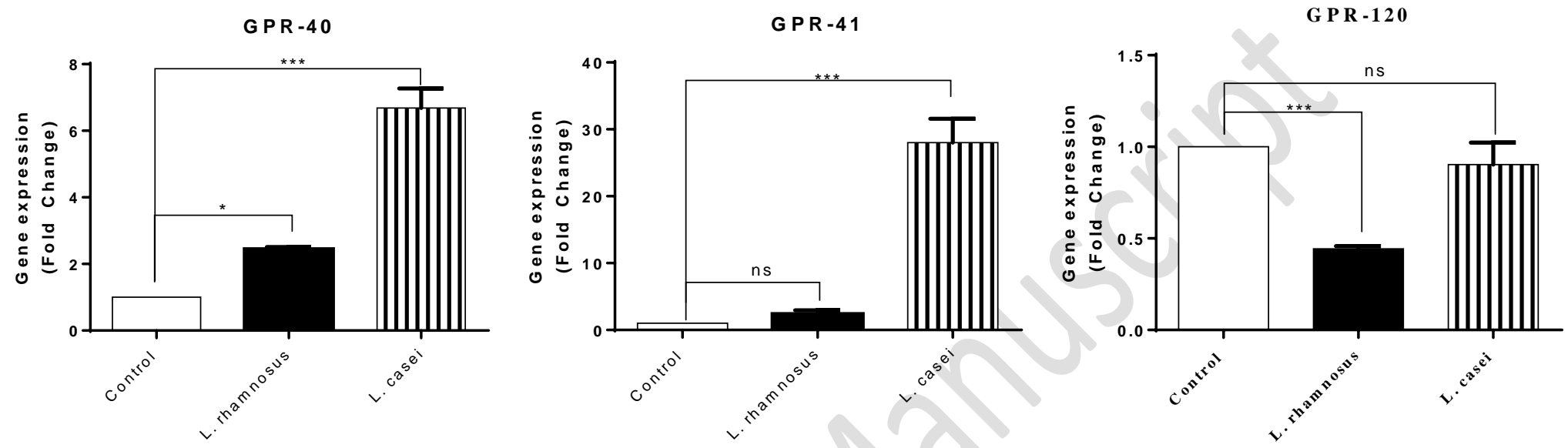
Figure 4

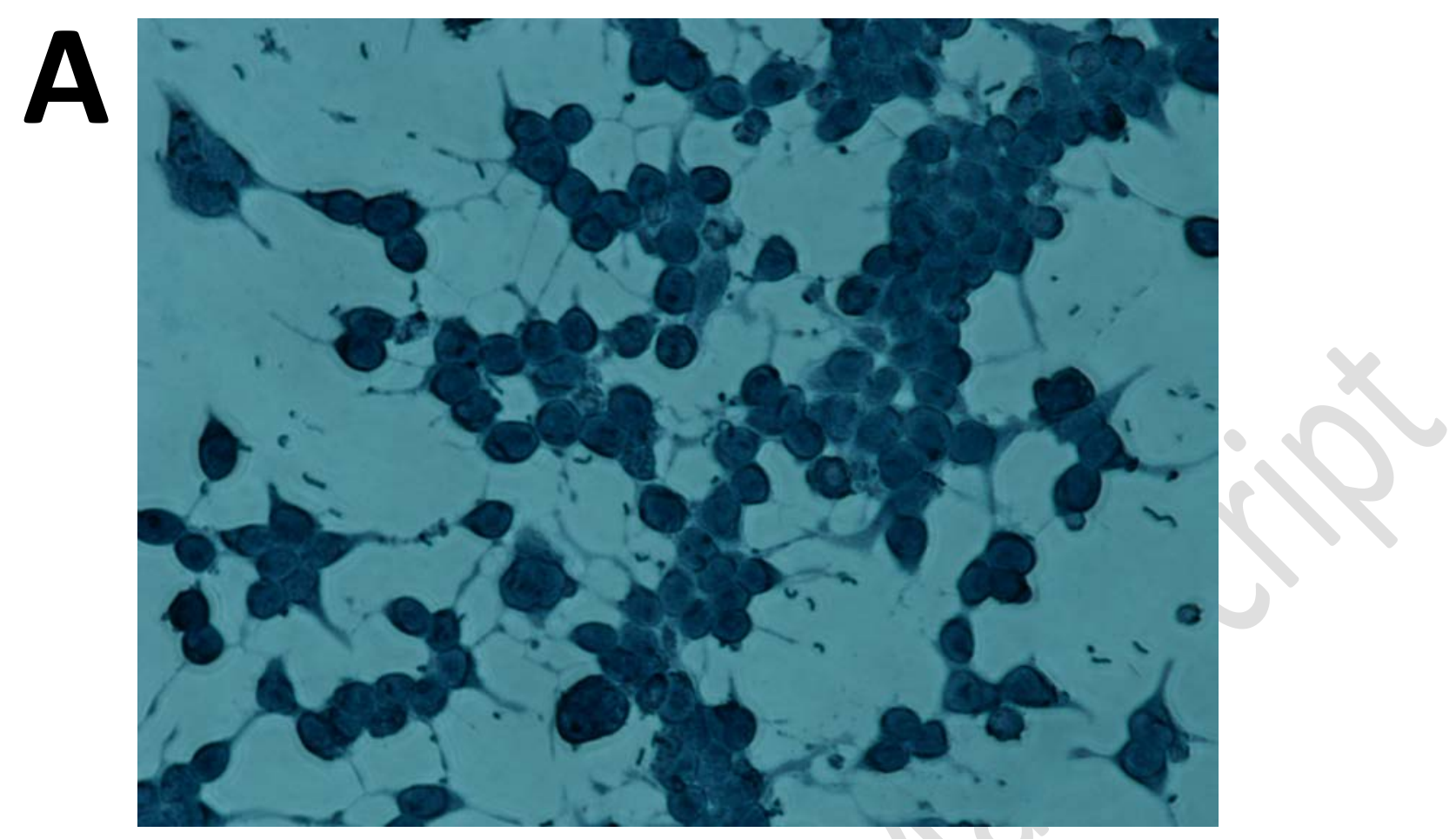




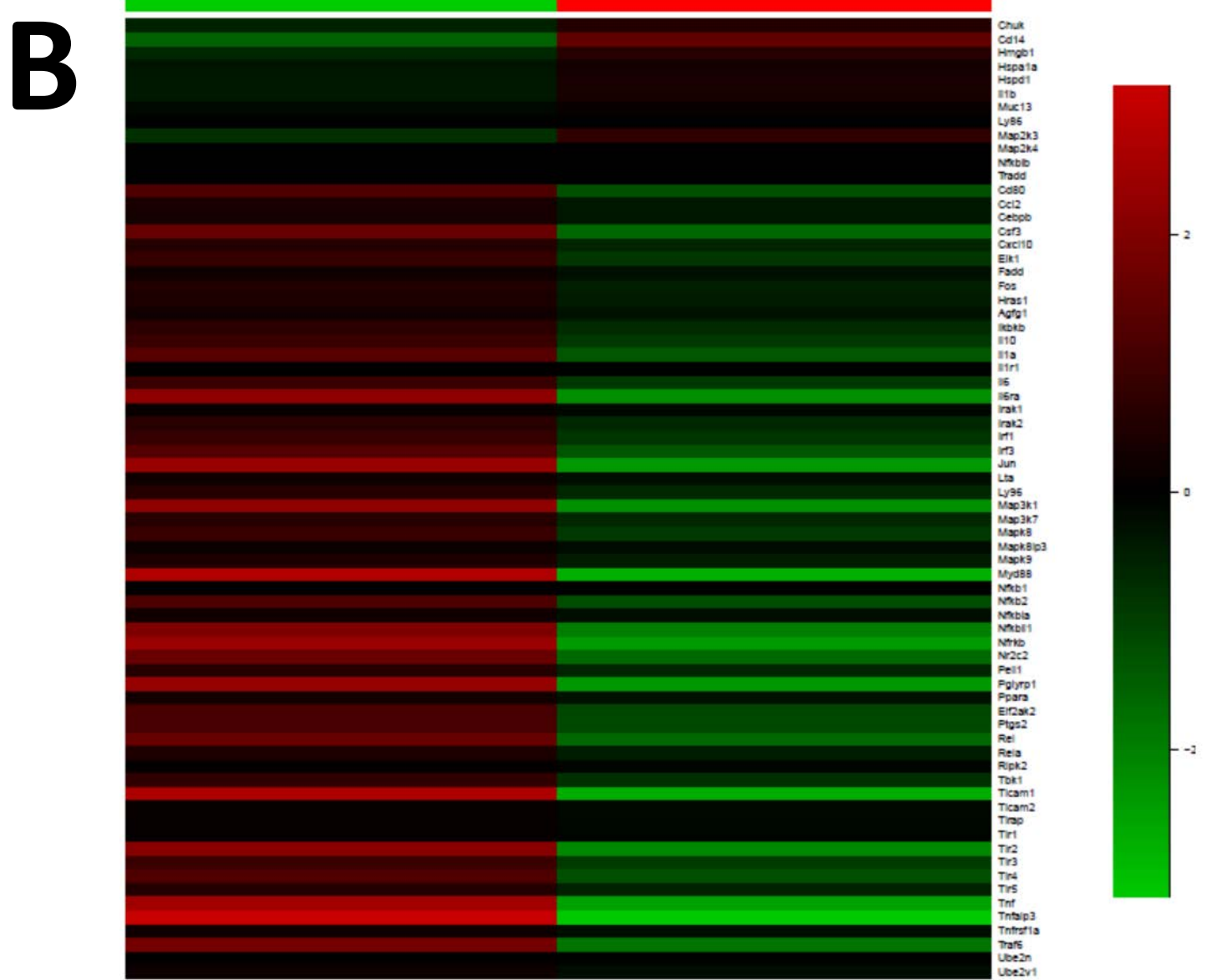

Control

L. rhamnosus 


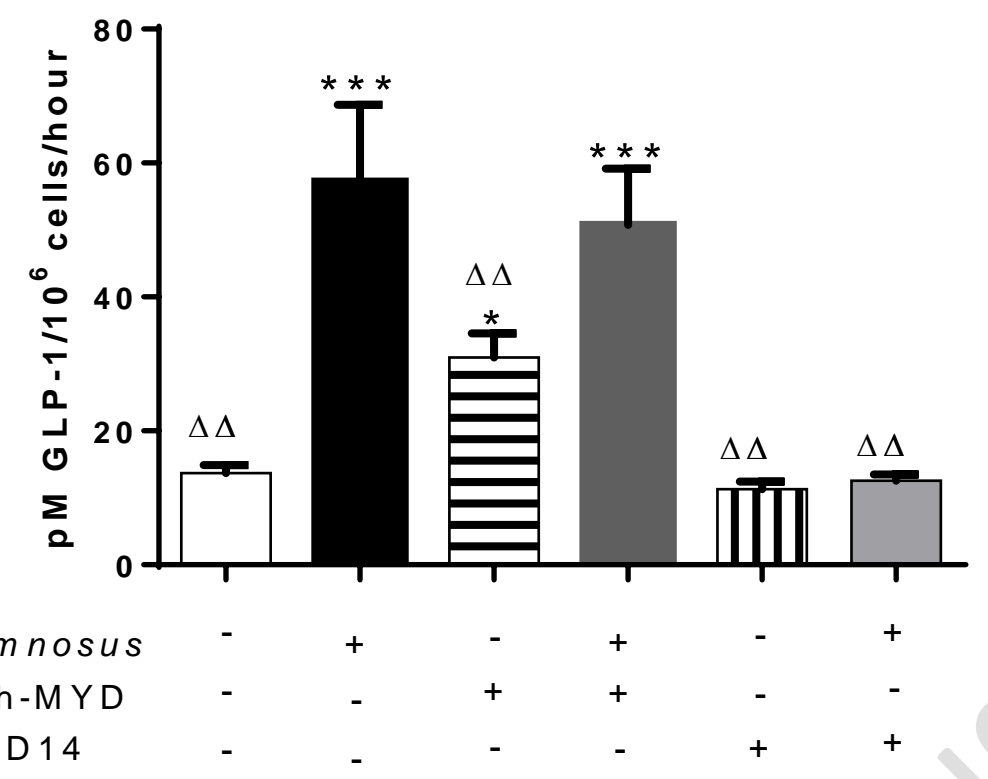




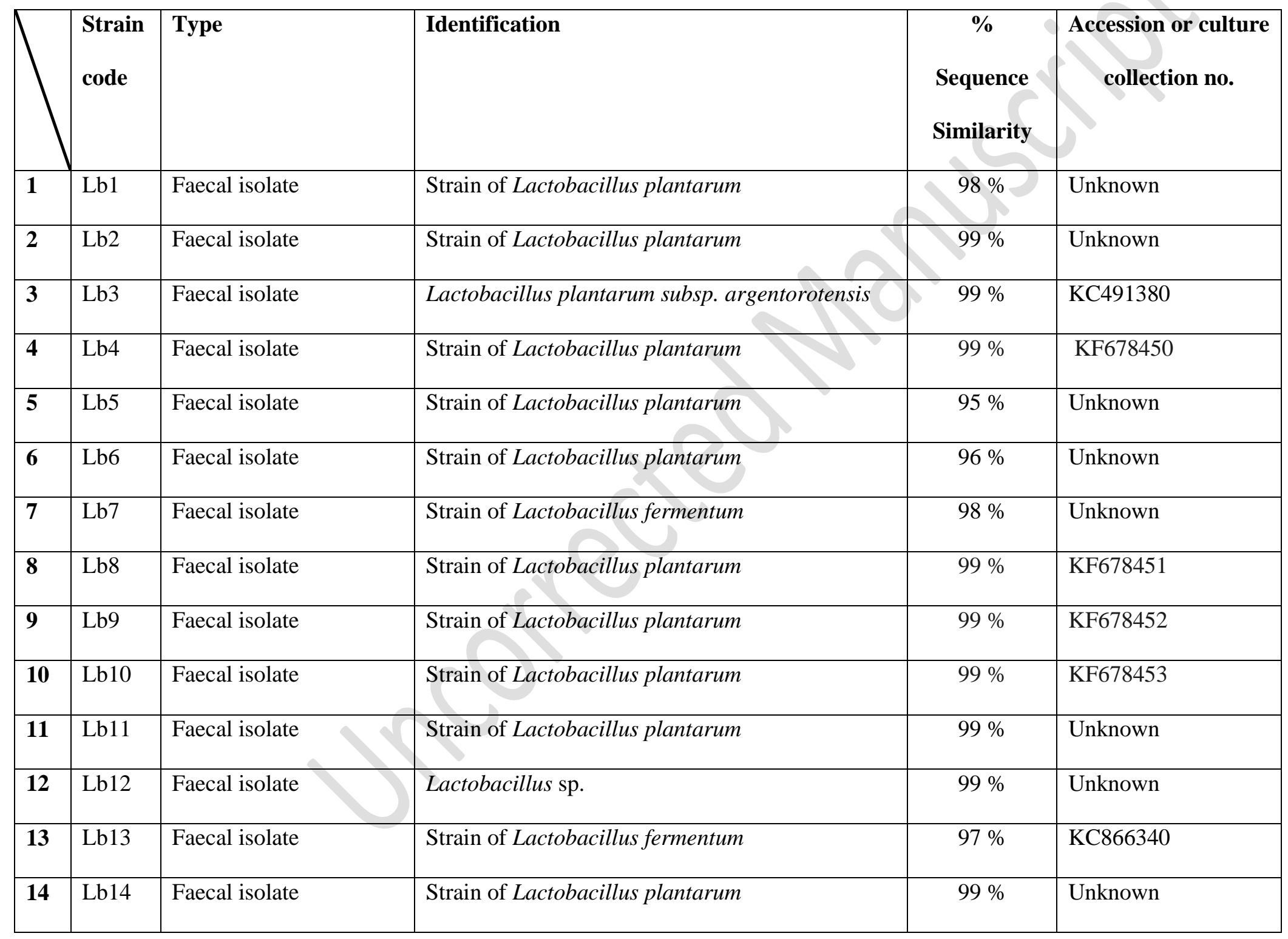




\begin{tabular}{|l|l|l|l|r|l|}
\hline $\mathbf{1 5}$ & Lb15 & Faecal isolate & Strain of Lactobacillus acidophilus & $99 \%$ & Unknown \\
\hline $\mathbf{1 6}$ & Ref1 & Reference culture & Lactobacillus acidophilus & n/a & NCIMB701748 \\
\hline $\mathbf{1 7}$ & Ref2 & Reference culture & Lactobacillus casei & n/a & NCIMB4114 \\
\hline $\mathbf{1 8}$ & Ref3 & Reference culture & Lactobacillus fermentum & n/a & NCIMB2797 \\
\hline $\mathbf{1 9}$ & Ref4 & Reference culture & Lactobacillus johnsonii & n/a & NCIMB8795 \\
\hline $\mathbf{2 0}$ & Ref5 & Reference culture & Lactobacillus paracasei & n/a & NCIMB1407 \\
\hline $\mathbf{2 1}$ & Ref6 & Reference culture & Lactobacillus plantarum & n/a & NCIMB1406 \\
\hline $\mathbf{2 2}$ & Ref7 & Reference culture & Lactobacillus rhamnosus & n/a & NCIMB702715 \\
\hline $\mathbf{2 3}$ & Ctrl1 & Gram positive control & Bifidobacterium bifidum & n/a & NCTC 10538 \\
\hline $\mathbf{2 4}$ & Ctrl2 & Gram negative control & Escherichia coli & & \\
\hline
\end{tabular}

Table 1. List of bacterial strains examined in the study. Bacterial strains Lb-1 to Lb15 were isolated from faeces from healthy human infants.

Reference strains (Ref1-7) were obtained from NCIMB. n/a- not applicable. 
Table 2 Primer sequences used in this study

\begin{tabular}{|c|c|c|c|}
\hline Target & Forward & Reverse & Reference \\
\hline $\begin{array}{l}\text { Proglucagon } \\
\text { (GLP-1) }\end{array}$ & $\begin{array}{l}\text { Proglucagon-F } \\
\text { 5'- ggcacattcaccagcgactac -3', }\end{array}$ & $\begin{array}{l}\text { Proglucagon-R } \\
\text { 5'- caatggcgacttcttctggg -3, }\end{array}$ & Rasouli et al.,2011 \\
\hline GIP & $\begin{array}{l}\text { GIP-F } \\
\text { 5'- gaagacctgctctctgttgctggt }-3 \text {, }\end{array}$ & $\begin{array}{l}\text { GIP-R } \\
\text { 5'- cagagctctgcttggtccaccatc }-3 \text { ' }\end{array}$ & Jepeal et al., 2008 \\
\hline$\beta$-actin & $\begin{array}{l}\beta \text {-actin-F } \\
\text { 5'- gtgtgatggtgggaatgggtc }-3 \text {, }\end{array}$ & $\begin{array}{l}\beta \text {-actin-R } \\
5 \text { '- aggaagaggatgcggcagtg -3, }\end{array}$ & Rasouli et al.,2011 \\
\hline GPR40 & $\begin{array}{l}\text { GPR40-F } \\
\text { 5'- agtcctcgtcacacatattg }-3,\end{array}$ & $\begin{array}{l}\text { GPR40-R } \\
\text { 5'- aatgcctccaatgtggatag -3' }\end{array}$ & Katsuma et al., 2005 \\
\hline GPR41 & $\begin{array}{l}\text { GPR 41-F } \\
\text { 5'- ttcttgcagccacactgctc }-3 \text {, }\end{array}$ & $\begin{array}{l}\text { GPR 41-R } \\
\text { 5'- gcccaccacatgggacatat }-3^{\prime}\end{array}$ & Brown et al. 2003 \\
\hline GPR120 & $\begin{array}{l}\text { GPR 120-F } \\
\text { 5'- gcataggagaaatctcatgg }-3,\end{array}$ & $\begin{array}{l}\text { GPR 120-R } \\
\text { 5'- gagttggcaaacgtgaaggc }-3 '\end{array}$ & Katsuma et al., 2005 \\
\hline LbLMA1/R-161 & $\begin{array}{l}\text { LbLMA1/R-161-F } \\
\text { 5'- ctcaaaactaaacaaagtttc -3' }\end{array}$ & $\begin{array}{l}\text { LbLMA1/R-161-R } \\
\text { 5'-ctcgtacttgtacacaccgccegtca -3' }\end{array}$ & Dubernet et al., 2002 \\
\hline 16SrRNA & $\begin{array}{l}\text { 16SrRNA-F } \\
\text { 5'- ccagagtttgatcmtggctcag -3' }\end{array}$ & $\begin{array}{l}\text { 16SrRNA-R } \\
\text { 5'- cggttaccttgttacgacttcacc -3' }\end{array}$ & $\begin{array}{l}\text { Turner et al., 1999; } \\
\text { Rogall et al., } 1990\end{array}$ \\
\hline Phe & $\begin{array}{l}\text { Phe-F } \\
\text { 5'- tatttcaaaattgcraaacgr -3'; }\end{array}$ & $\begin{array}{l}\text { Phe-R } \\
\text { 5'- cccwgcwcgtgatatgca -3, }\end{array}$ & Naser et al., 2007 \\
\hline
\end{tabular}




\begin{tabular}{|c|c|c|c|c|c|c|c|}
\hline Genes & Refseq & \multirow{2}{*}{\multicolumn{2}{|c|}{ Fold Changes }} & \multicolumn{2}{|c|}{ Genes Refseq } & \multicolumn{2}{|c|}{ Fold Changes } \\
\hline \multicolumn{2}{|c|}{ Toll-like receptors } & & & \multicolumn{4}{|c|}{ NF kappa B pathway } \\
\hline TIr1 & NM_030682 & 1.84 & & $\mathrm{Ccl} 2$ & NM 011333 & 1.16 & \\
\hline TIr2 & NM_011905 & -9.71 & * & Chuk & NM_007700 & 4.38 & * \\
\hline TIr3 & NM_126166 & -1.75 & & Csf2 & NM_009969 & 2.02 & * \\
\hline TIr4 & NM_021297 & -2.79 & * & Csf3 & NM_009971 & -4.62 & * \\
\hline TIr5 & NM_016928 & -1.06 & & Agfg1 & NM_010472 & 1.31 & \\
\hline TIr6 & NM_011604 & 2.02 & * & Ikbkb & NM_010546 & -1.27 & \\
\hline TIr7 & NM_133211 & 2.02 & * & II & NM_010554 & -3.20 & * \\
\hline TIr8 & NM_133212 & 2.02 & * & $\| 1 b$ & NM_008361 & 3.41 & * \\
\hline TIr9 & NM_031178 & 2.02 & * & IIr1 & NM_008362 & 1.88 & \\
\hline Muc13 & NM_010739 & 2.50 & * & $\| 2$ & NM_008366 & 2.02 & * \\
\hline \multicolumn{4}{|c|}{ Adaptors \& interacting proteins } & 116 & NM 031168 & -1.72 & \\
\hline Btk & NM 013482 & -2.48 & * & II10 & NM 010548 & -1.73 & \\
\hline Cd14 & NM 009841 & 17.52 & * & $\| 12 \mathrm{a}$ & NM 008351 & 2.02 & * \\
\hline Hmgb1 & NM 010439 & 4.93 & * & Map3k1 & NM 011945 & - & * \\
\hline Hras1 & NM_008284 & 1.14 & & Nfkb1 & NM_008689 & 1.88 & \\
\hline Hspala & NM_010479 & 3.18 & * & Nfkb2 & NM_019408 & -2.64 & * \\
\hline Hspd1 & NM_010477 & 3.53 & * & Nfkbia & NM_010907 & 1.43 & \\
\hline Lta & NM_010735 & 1.45 & & Nfkbib & NM_010908 & 2.17 & * \\
\hline Ly86 & NM_010745 & 2.03 & * & Nfkbil1 & NM_010909 & -7.89 & * \\
\hline Ly96 & NM_016923 & -1.15 & & Nfrkb & NM_172766 & - & * \\
\hline Mapk8ip3 & NM_013931 & 1.57 & & Rel & NM_009044 & -4.72 & * \\
\hline Myd88 & NM_010851 & -23.41 & * & Rela & NM_009045 & 1.06 & \\
\hline Peli1 & NM_023324 & -1.09 & & Tnf & NM_013693 & - & * \\
\hline Pglyrp1 & NM_009402 & -12.99 & * & Tnfaip3 & NM_009397 & - & * \\
\hline Ripk2 & NM 138952 & 1.83 & & Tnfrsf1a & NM 011609 & 1.50 & \\
\hline Ticam1 & NM 174989 & -21.69 & * & Tradd & NM_001033161 & 2.07 & * \\
\hline Ticam2 & NM 173394 & 1.63 & & \multicolumn{4}{|c|}{ JNK/p38 pathway } \\
\hline Tirap & NM 054096 & 1.75 & & Elk1 & NM 007922 & -1.62 & \\
\hline Tollip & NM 023764 & 2.02 & * & Fos & NM 010234 & -1.01 & \\
\hline Effectors & & & & Jun & NM 010591 & - & * \\
\hline Casp8 & NM 009812 & 3.73 & * & Map2k3 & NM 008928 & 5.82 & * \\
\hline Fadd & NM_010175 & 1.41 & & Map2k4 & NM_009157 & 2.04 & * \\
\hline Irak1 & NM_008363 & 1.67 & & Mapk8 & NM_016700 & -1.73 & \\
\hline Irak2 & NM_172161 & -1.23 & & Mapk9 & NM_016961 & 1.07 & \\
\hline Map3k7 & NM_172688 & -1.18 & & \multicolumn{4}{|c|}{ NF/IL6 pathway } \\
\hline $\mathrm{Nr} 2 \mathrm{c} 2$ & NM_011630 & -4.89 & * & Cebpb & NM_009883 & 1.28 & \\
\hline Ppara & NM_011144 & 1.35 & & Clec4e & NM_019948 & 2.02 & * \\
\hline Eif2ak2 & NM_011163 & -2.31 & * & II6ra & NM_010559 & - & * \\
\hline Ube2n & NM_080560 & 1.92 & & Ptgs2 & NM_011198 & -2.41 & * \\
\hline Ube2v1 & NM_023230 & 1.50 & & \multicolumn{4}{|c|}{ Adaptive Immunity } \\
\hline IRF pathway & 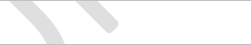 & & & Cd80 & NM_009855 & -2.71 & * \\
\hline$\overline{\mathrm{Cxcl} 10}$ & NM_021274 & -1.12 & & Cd86 & NM_019388 & 2.02 & * \\
\hline Ifnb1 & NM_010510 & 2.02 & * & Traf6 & NM_009424 & -6.14 & * \\
\hline Ifng & NM_008337 & 2.02 & * & & & & \\
\hline Irf1 & NM_008390 & -1.59 & & & & & \\
\hline Irf3 & NM_016849 & -3.14 & * & & & & \\
\hline Tbk1 & NM_019786 & -1.44 & & & & & \\
\hline
\end{tabular}

Supplementary Table 1: TLR Gene Array: changes in gene expression in pGIP/Neo STC-1 cells following co-culture with $L$. rhamnosus. Note:- Positive fold change indicates up-regulation. Negative fold change indicates downregulation. $* \mathrm{P}<0.05$. 